\title{
RMI2 wt Allele
}

National Cancer Institute

\section{Source}

National Cancer Institute. RMI2 wt Allele. NCI Thesaurus. Code C96028.

Human RMI2 wild-type allele is located in the vicinity of $16 \mathrm{p} 13.13$ and is approximately 6 $\mathrm{kb}$ in length. This allele, which encodes RecQ-mediated genome instability protein 2, plays a role in the regulation of homologous recombination. 